\title{
Luxembourg: Political developments and data in 2018
}

\author{
RAPHAËL KIES, ${ }^{1}$ PATRICK DUMONT ${ }^{2} \&$ DAN SCHMIT ${ }^{1}$ \\ ${ }^{1}$ University of Luxembourg, Luxembourg; ${ }^{2}$ Australian National University, Australia
}

\section{Introduction}

The 2018 political year was dominated by the parliamentary elections on 14 October 2018. The general expectation was that the Christian Democrats (CSV), who had been in opposition since 2013, would win the election and return to government. In the end, they lost votes and the incumbent coalition of Liberals (DP), Social Democrats (LSAP) and Greens (Déi Gréng) could maintain its majority, allowing the three parties to continue for a second term. These elections also led to the rise of the Pirate Party.

On the legislative front, several bills on the government's legislative agenda were voted on by Parliament.

\section{Election report}

Parliamentary elections took place on 14 October 2018 at the end of the first term with the CSV in opposition since 1979. After suffering losses at the 2013 election (Dumont \& Kies 2014), polls suggested that the CSV would win votes and that no coalition without the party would be possible. Final polls in June 2018 indicated that due to a collapse in socialist and liberal votes, the incumbent coalition would no longer have a majority in Parliament, largely due to a CSV that would win back the seats lost in 2013, and that the preferred coalition option was CSV-Greens, given the expected good results for the smallest of the coalition parties. Another party that was expected to benefit from the election, following the electoral successes of populist parties in neighbouring countries, was the Democratic Reform Party (ADR) with its conservative and sovereigntist programme centred around the defence of national identity and language.

\section{Campaign}

There were 547 candidates officially on the lists of the nine political parties or parties: DP, LSAP, Déi Gréng, CSV, ADR, Déi Lénk, Luxembourg Communist Party (KPL), Piratepartei and Déi Konservativ. Furthermore, a group labelled 'Demokratie' presented lists in the Centre and South electoral districts. Ultimately that party did not take part in the campaign after it emerged that several candidates had been put on the list after having been deceived about what form they were signing. It had, however, not been possible to remove the candidate lists from the ballot because these facts were only revealed after the deadline to make changes or withdraw candidate lists. 
Table 1. Elections to the Chamber of Deputies (Chambre des Députés) in Luxembourg in 2018

\begin{tabular}{|c|c|c|c|c|c|c|c|c|}
\hline Date of election & \multicolumn{2}{|c|}{14 October 2018} & \multicolumn{4}{|c|}{ Previous election } & \multicolumn{2}{|c|}{20 October 2013} \\
\hline Electorate & \multicolumn{2}{|l|}{259,887} & \multicolumn{3}{|c|}{ Total seats } & & \multicolumn{2}{|l|}{60} \\
\hline Total votes cast & \multicolumn{2}{|l|}{233,014} & \multicolumn{3}{|c|}{ Turnout (\%) } & & \multicolumn{2}{|c|}{$89.66 \%$} \\
\hline Valid votes cast & \multicolumn{2}{|l|}{216,177} & \multicolumn{4}{|c|}{ Share of valid vote $(\%)$} & \multicolumn{2}{|c|}{$92.77 \%$} \\
\hline & & \multicolumn{3}{|c|}{ Votes } & \multicolumn{4}{|c|}{ Seats } \\
\hline \multicolumn{2}{|l|}{ Party } & $N^{\mathrm{a}}$ & $\%$ & $\Delta \%$ & $N$ & $\%$ & $\Delta N$ & $\Delta \%$ \\
\hline \multicolumn{9}{|c|}{$\begin{array}{l}\text { Party/Chrëschtlech-Sozial } \\
\text { Vollekspartei (CSV) }\end{array}$} \\
\hline \multicolumn{3}{|c|}{$\begin{array}{l}\text { Democratic Party/Demokratesch Partei35454 } \\
\text { (DP) }\end{array}$} & $17.5 \%$ & $-1.6 \%$ & 12 & $20.0 \%$ & -1 & $-1.7 \%$ \\
\hline \multicolumn{2}{|c|}{$\begin{array}{l}\text { Luxembourg's Socialist Workers' } \\
\text { Party/Lëtzebuerger Sozialistesch } \\
\text { Aarbechterpartei (LSAP) }\end{array}$} & 33981 & $16.8 \%$ & $-2.4 \%$ & 10 & $16.7 \%$ & -3 & $-5.0 \%$ \\
\hline \multicolumn{2}{|c|}{ The Greens/Déi Gréng (DG) } & 30487 & $15.1 \%$ & $+4.8 \%$ & 9 & $15.0 \%$ & +3 & $+5.0 \%$ \\
\hline \multicolumn{2}{|c|}{$\begin{array}{l}\text { Democratic Reform Party/Altern } \\
\text { Demokratesch Reformpartei } \\
\text { (ADR) }\end{array}$} & 17336 & $8.6 \%$ & $+1.8 \%$ & 4 & $6.7 \%$ & +1 & $+1.7 \%$ \\
\hline \multicolumn{2}{|c|}{ Pirate Party/Piratepartei (PP) } & 13,394 & $6.6 \%$ & $+3.6 \%$ & 2 & $3.3 \%$ & +2 & $+3.3 \%$ \\
\hline \multicolumn{2}{|c|}{ The Left/Déi Lénk (DL) } & 10208 & $5.0 \%$ & $+0.5 \%$ & 2 & $3.3 \%$ & 0 & $0.0 \%$ \\
\hline \multicolumn{2}{|c|}{$\begin{array}{l}\text { Luxembourg Communist } \\
\text { Party/Kommunistesch Partei } \\
\text { Lëtzebuerg (KPL) }\end{array}$} & 2311 & $1.1 \%$ & $-0.3 \%$ & 0 & $0.0 \%$ & 0 & $0.0 \%$ \\
\hline \multicolumn{2}{|c|}{$\begin{array}{l}\text { The Conservatives/Déi Konservativ } \\
\text { (DK) }\end{array}$} & 418 & $0.2 \%$ & $+0.2 \%$ & 0 & $0.0 \%$ & 0 & $0.0 \%$ \\
\hline \multicolumn{2}{|c|}{ Democracy/Demokratie (Demo) } & 465 & $0.2 \%$ & $+0.2 \%$ & 0 & $0.0 \%$ & 0 & $0.0 \%$ \\
\hline
\end{tabular}

Note: 'a'Adjusted fictitious voters' figures; see Dumont \& Poirier (2006: 1103) for details of the method of computation of this measure allowing one to give a distribution of votes summing to the total number of actual valid votes. The percentage of votes in the next column refers to the 'fictitious voters' scores of each party, which is the usual way of presenting results in Luxembourg (and in the EJPR PDY) by weighting their results across the four constituencies rather than presenting the absolute sum of votes (which, given the electoral system awarding as many votes as there are MPs to be elected in the constituency, would overrepresent the two large ones).

Source: Service information et presse (2018).

There was a significant increase of female candidates, with up to 46 per cent of candidates being women. This was largely due to the 2016 law that amended the 2007 Law on the Financing of Political Parties (as well as the labour code, by inserting several articles pertaining to gender wage equality) and introduced an incentive mechanism linking state funding to the gender balance of parties' electoral lists. ${ }^{1}$ Despite the introduction of quotas, fewer women were elected than in 2013 (Table 4, but note that their representation in Cabinet increased in the newly formed government; see also Tables 2 and 3), probably due to the fact that women remained largely underrepresented in the public debates and the media during the campaign (De Jonge \& Biwer 2018).

As an indirect consequence of the introduction of quotas, the share of first-timer candidates is particularly high. The record is held by the ADR with 41 new faces. The other 
Table 2. Cabinet composition of Bettel I Cabinet in Luxembourg in 2018

\begin{tabular}{lllll}
\hline $\begin{array}{l}\text { Duration of Cabinet } \\
\text { Period covered by table } \\
\text { Type of Cabinet }\end{array}$ & Inception & 4 December 2013 & Dissolution & 5 December 2018 \\
Minimum winning coalition (MWC) & & Until & 5 December 2018 \\
\hline
\end{tabular}

\begin{tabular}{lrrrrrr} 
A. Party/gender composition on & \multicolumn{3}{c}{ Seats in Cabinet Seats held by women } & \multicolumn{3}{c}{ Seats in Parliament } \\
1 January 2018 & $N$ & \multicolumn{1}{c}{$\%$} & $N$ & $\%$ of party & $N$ & $\%$ \\
\hline Democratic Party (DP) & 7 & $38.9 \%$ & 1 & $14.3 \%$ & 13 & $21.6 \%$ \\
Luxembourg's Socialist Workers' Party & 7 & $38.9 \%$ & 2 & $28.6 \%$ & 13 & $21.6 \%$ \\
(LSAP) & & & & & & \\
The Greens (DG) & 4 & $22.2 \%$ & 1 & $25.0 \%$ & 6 & $10.0 \%$ \\
Totals & 18 & $100.0 \%$ & 4 & $22.2 \% \%$ & 32 & $53.3 \%$ \\
\hline
\end{tabular}

B. Composition of Bettel I Cabinet on 1 January 2018

See previous editions of the Political Data Yearbook for Luxembourg or http://politicaldatayearbook.com

C. Changes in composition of Bettel I Cabinet during 2018

\begin{tabular}{lllll} 
Ministerial title & Outgoing minister & Outgoing date & Incoming minister & Comments \\
\hline $\begin{array}{l}\text { State Secretary for } \\
\text { Sustainable }\end{array}$ & Camille Gira (1958, 16 May 2018 & Claude Turmes & Death \\
$\begin{array}{l}\text { Development, } \\
\text { Infrastructure and } \\
\text { the Environment }\end{array}$ & & & \\
\hline
\end{tabular}

D. Party/gender composition on 5 December 2018

No change during 2018

Source: www.gouvernement.lu.

parties have listed about one-third of new faces, intended to compose, for a part of them, the future Luxembourgish political class (Hennebert 2018).

The CSV, under the leadership of Claude Wiseler, started the campaign as clear favourite. Following the catastrophic results for the coalition in the 2015 referendum (Dumont \& Kies 2016), the success of the last local elections (Dumont \& Kies 2018) and positive opinion polls, it had the strong conviction that it would return to government as the leading party. The main question that occupied the journalists during the campaign was therefore to guess who would become its junior partner. Would it be, as in the past, the LSAP or the DP, or would the CSV opt for an innovative alliance with Déi Gréng? Probably as a consequence of this optimism, the Christian Democrats revealed their programme late in the campaign with the slogan 'Mir hunn ee Plang'2 (i.e., 'We have a plan') and adopted a conciliatory attitude with their main opponents. In particular, Wiseler was considered too mild during the electoral debates, even among the supporters of its own party.

Under the leadership of the incumbent Vice-Prime Minister Etienne Schneider, the LSAP promoted a more aggressive and leftist campaign under the slogan 'Zesummen' (i.e., Together) aiming at keeping and regaining its traditional electorate and to stay in 
government. The LSAP perceived this election as the opportunity to stop its decline that reached its bottom in the past national election (Dumont \& Kies 2014). As a symbol of this evolution, it promoted an increase of $€ 100$ per month for the minimum social wage and the introduction of a 38-hour week coupled with a sixth week of leave in the private sector, to compensate for the expected consequences of the digital transformation.

While the Social Democrats attempted to win votes by returning to their traditional electorate, the Liberal party tried to capitalize on its two most charismatic figures, the incumbent Prime Minister, Xavier Bettel, and the Minister of Family and Social Affairs, Corinne Cahen (who introduced parental leave in the past legislature, a reform that was widely appreciated). Despite a slogan promoting Luxemburgish identity, 'Zukunft op Lëtzebuergesch' ('Future in Luxembourgish'), its programme was essentially liberal. Its main campaign issues were to further facilitate working and family life, to provide tax relief for small and medium-sized enterprises, and to introduce free public transport and the legalizing cannabis for non-medical purposes.

The Green Party entered this competition with the intention of staying in government as part of a two or three parties' coalition. With the motto 'Zukunft, Zesummenhalt, gutt liewen. Well mer eist Land gär hunn' ('Future, good life, cohesion - because we love our country'), Déi Gréng aimed to support sustainable development, improve public transport and the green economy. As for the 2013 elections, its main campaign figure was the incumbent Minister for Sustainable Development and Infrastructure, François Bausch.

On the left side of the political spectrum, Déi Lénk aimed to become the only left alternative at the expense of both the Social Democrats and KPL, while at the same time a valid alternative to the Greens. With the slogan 'Engagéiert fir Verännerung' ('Committed to change'), it promoted strong environmental protection, a substantial increase of the minimum wage, a 32-hour working week, increased taxes for large corporations and affordable housing through the construction of public housing.

On the right side of the spectrum, the ADR made an electoral alliance with the Wee 2050/Nee 2015 movement, which had formed itself as a citizen's movement fighting for the ' $3 \times$ no' in the 2015 referendum' (Dumont \& Kies 2016). Through this alliance and the inclusion of its public figure (Fred Keup) among its candidates, the ADR tried to reinforce further its identity profile, as was well illustrated by its slogan 'Är Stëmm fir Lëtzebuerg' ('Your voice for Luxembourg'). It also insisted on a sustainable pension scheme. Further on the right side of the spectrum, the ADR had to face the competition of the newly formed Konservativ Party, which presented itself as the best party to protect national identity, culture and conservative values. Its motto was 'Lëtzebuerg: modern a fair fir jiddereen' ('Luxembourg: modern and fair for everybody').

Even though the campaign was intense, no party was able to impose its agenda. As a sign of indecision and potential high volatility, many voters postponed their electoral choice until the very last moment - that is, 40 per cent made their choice during the last week of the campaign. Moreover, for the first time their electoral choice was more heavily influenced by issues related to quality of life - in particular, affordable housing, transport and ecology than by identity or the economy (Kies et al.2019). 
Table 3. Cabinet composition of Bettel II Cabinet in Luxembourg in 2018

\begin{tabular}{|c|c|c|c|}
\hline Duration of Cabinet & 5 December 2018 & Dissolution & Still in office at end of the year \\
\hline Period covered by table & 5 December 2018 & Until & 31 December 2018 \\
\hline Type of Cabinet & Minimum winning coalition ( & IWC) & \\
\hline
\end{tabular}

\begin{tabular}{|c|c|c|c|c|c|c|}
\hline \multirow{2}{*}{$\begin{array}{l}\text { A. Party/gender composition on } \\
5 \text { December } 2018\end{array}$} & \multicolumn{2}{|c|}{ Seats in Cabinet } & \multicolumn{2}{|c|}{ Seats held by women } & \multicolumn{2}{|c|}{ Seats in Parliament } \\
\hline & $N$ & $\%$ & $N$ & $\%$ of party & $N$ & $\%$ \\
\hline Democratic Party (DP) & 6 & $35.3 \%$ & 1 & $16.6 \%$ & 12 & $20.0 \%$ \\
\hline $\begin{array}{l}\text { Luxembourg's Socialist Workers' Party } \\
\text { (LSAP) }\end{array}$ & 6 & $35.3 \%$ & 2 & $33.3 \%$ & 10 & $16.6 \%$ \\
\hline The Greens (DG) & 5 & $29.4 \%$ & 2 & $40.0 \%$ & 9 & $15.0 \%$ \\
\hline Totals & 17 & $100.0 \%$ & 5 & $29.4 \%$ & 31 & $51.6 \%$ \\
\hline
\end{tabular}

B. Composition of Bettel II Cabinet on Cabinet inception date 5 December 2018

Ministerial title

Minister

Prime Minister, Minister for Media and Communication, Xavier Bettel (1973, male, DP)

Digitalisation and Administrative Reform

Deputy Prime Minister, Minister of the Economy, Minister Etienne Schneider (1971, male, LSAP) for Health

Deputy Prime Minister, Minister for Justice

Felix Braz (1966, male, DG)

Minister for Finance

Pierre Gramegna (1958, male, DP)

Minister for Foreign and European Affairs, Immigration and Asylum

Minister for Transport, Infrastructure, Defence and Domestic Security

Minister for Education, Higher Education and Research

Minister for Family, Integration and the Greater Region

Minister for Housing, Minister for Culture

Minister for Small and Medium Business, Minister for Tourism

Minister of the Civil Service, Minister for Parliamentary Relations, Delegated Minister for Digitalisation and Administrative Reform

Minister for Agriculture, Minister for Social Security

Minister for Employment, Minister for Sports

Jean Asselborn (1949, male, LSAP)

François Bausch (1956, male, DG)

Claude Meisch (1971, male, DP)

Corinne Cahen (1973, female, DP)

Sam Tanson (1977, female, DG)

Lex Delles (1984, male, DP)

Marc Hansen (1971, male, DP)

Minister of the Interior, Minister for Equal Opportunities

Minister for International Cooperation, Minister for Consumer Protection

Minister for Sustainable Development, the Environment and Climate

Minister for Energy and Land Planning

Romain Schneider (1962, male, LSAP)

Dan Kersch (1961, male, LSAP)

Taina Bofferding (1982, female, LSAP)

Paulette Lenert (1968, female, LSAP)

Carole Dieschbourg (1977, female, DG)

Claude Turmes (1960, male, DG)

C. Changes in composition of Bettel II Cabinet during 2018

Ministerial title Outgoing minister Outgoing date

Incoming minister

Comments

None

D. Party/gender composition on 31 December 2018

No change during 2018

Source: www.gouvernement.lu. 


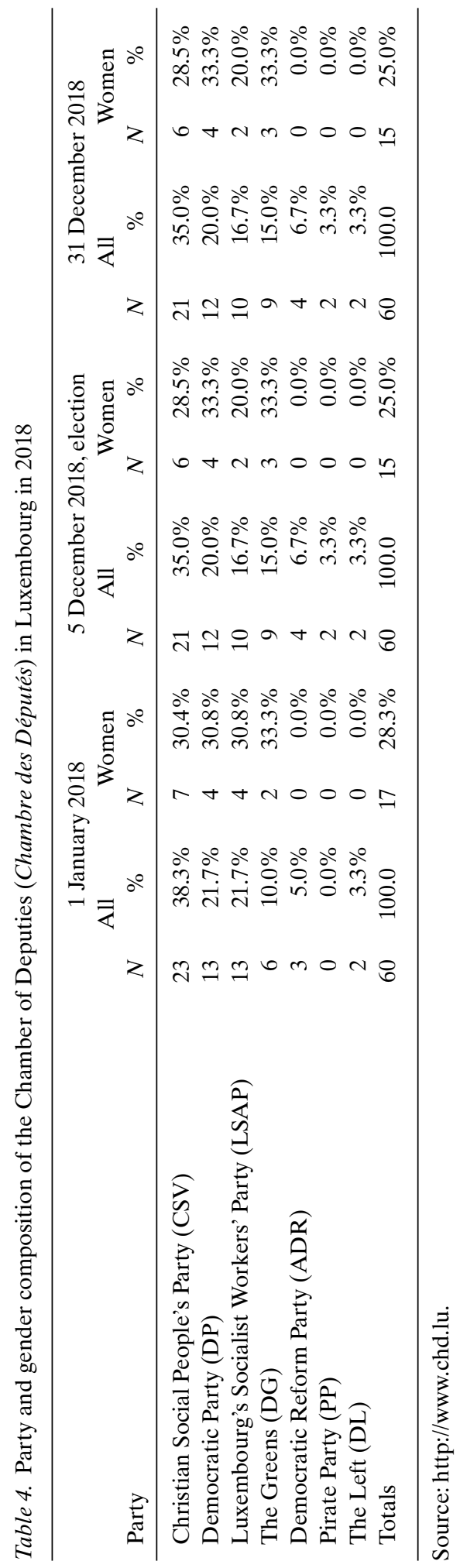




\section{Results}

The election results defied several expectations; most importantly, the Christian Democrats lost over 5 percentage points in the votes, leading to the party's worst performance since the Second World War. While substantial losses for the coalition parties were expected, their aggregate vote share increased. This is primarily due to a large increase of the Greens' vote share, which outweighed the Social Democrats' loss and only a marginal loss of the Democratic Party. The conservative and sovereigntist ADR party increased its vote share, although by less than expected. On the other hand, the Pirate Party doubled its vote share, which allowed it to win its first two parliamentary seats. The Left and the Communist Party remained relatively stable while two new parties, the Conservatives and Democracy, only obtained 0.2 per cent of the national votes.

Following the substantial losses of the Christian Democrats and maintaining a parliamentary majority of 31 of the 60 seats, the incumbent coalition parties quickly agreed to engage in coalition negotiations for a second term of the DP-LSAP-Greens coalition. This is considered a significant shift in the Luxembourg party system because the CSV, which has dominated Luxembourg's political system since the Second World War, will be an opposition party for two consecutive terms, deeply harming the party's narrative that it is the central party to maintain stability in Luxembourg.

\section{Coalition agreement}

On 3 December 2018, party representatives from the DP, LSAP and Déi Gréng formally signed a coalition agreement to govern Luxembourg for the next five years. The agreement outlines a policy programme that includes a pledge to make changes to the constitution (which will be subject to a referendum), to create more affordable housing, to make public transport free of charge starting in 2020, to legalize the recreational use of cannabis, to increase the minimum wage by $€ 100$ per month, and to reduce corporate taxes. Personal tax will in future be levied on individuals in a single category, doing away with the two-tier system that distinguished singles and married or couples in a civil partnership. The coalition programme has also set long-term targets to have 20 per cent of all agricultural production organic by 2025 and to end the use of glyphosate by 2020 .

\section{Cabinet report}

On 16 May 2018, Camille Gira, State Secretary (Junior Minister) for the Environment, Sustainable Development and Infrastructure suffered a heart attack during a parliamentary speech and died a few hours later in hospital. Two weeks later the Greens nominated Claude Turmes, who had until then served as MEP, as his successor.

Following the parliamentary elections, the Grand Duke nominated Xavier Bettel, leader of the liberal DP, with the formation of a new government. The coalition negotiations between the incumbent government parties (DP, LSAP, Déi Gréng) began on 17 October and concluded on 29 November 2018. The competent bodies of the three parties accepted the results of the coalition agreement on 4 December 2018. The following day, the Grand Duke swore in the new Cabinet consisting of 17 members (instead of 18 in the preceding 
one). While Nicolas Schmit, Lydia Mutsch, Francine Closener (LSAP), Guy Arendt and Fernand Etgen (DP) are now longer part of the Cabinet, four new ministers were nominated: Paulette Lenert, Taina Bofferding (both LSAP), Sam Tanson (Déi Gréng) and Lex Delles (DP).

Xavier Bettel (DP) has been reappointed as Prime Minister and Etienne Schneider (LSAP) as Deputy Prime Minister. Felix Braz (Déi Gréng) has been appointed as Second Deputy Prime minister.

Some responsibilities have been allocated to different coalition parties. As winners of the elections, the Greens have received several portfolios from their coalition partners. From the liberal DP, they were transferred the responsibility for housing and culture. From the LSAP, they recovered the responsibilities for defence, domestic security and energy.

The LSAP has been given the Ministries for Agriculture and Consumer Protection from the DP. The latter recovered the responsibilities for small and medium-sized businesses, the civil service, and administrative reform as well as tourism from the Social Democrats. Furthermore, a new Ministry for Digitalisation has been created. Prime Minister Xavier Bettel (DP) will oversee the new ministry.

\section{Parliament report}

In spring 2018, four MPs decided they would retire. Anne Brasseur (DP) was replaced by Frank Colabianchi, Claude Adam (DG) by Sam Tanson, Roger Negri (LSAP) by Simone Asselborn-Bintz, and Marcel Oberweis (CSV) by Claudine Konsbruck. ${ }^{3}$ Such retirements tend to occur in the months preceding a parliamentary election.

Following the 2018 parliamentary elections, the Chamber of Deputies has given itself a new presidency. Fernand Etgen (DP) has been elected as president of the Parliament. Claude Wiseler (CSV), Mars Di Bartolomeo (LSAP) and Henri Kox (DG) have been selected as vice-presidents.

As a result of the elections, some presidencies of the party groups have changed. Martine Hansen has been elected as president of the CSV group and Josée Lorsché as president of the Greens' group. Eugène Berger (DP) and Alex Bodry (LSAP) remain presidents of their parliamentary groups, but Gilles Baum (DP) and Georges Engel (LSAP) will replace them during the legislature.

As the result of the elections, the Pirate Party has entered Parliament. The party has decided to form a technical group with the ADR. Such technical groups allow the parties that form them to benefit from similar advantages as parliamentary groups that need to consist of five members.

\section{Political party report}

In early 2018, the Pirate Party and the Party for Integral Democracy announced that they would work together for the parliamentary election. More precisely, candidates from the latter were put on the Pirate Party's candidate lists. 
The ADR party had a similar cooperation with the campaign group Wee 2050/Nee 2015, which had been influential in the 2015 referendum campaign. Several representatives, including the group's leader Fred Keup, were on the party's candidate list.

After the election defeats, the presidents and secretaries of the CSV and the LSAP announced that they would not stand for re-election on their party conferences in early 2019.

\section{Institutional change report}

In February, a law abolishing church wardens was voted with the votes of the majority parties and the Left (Dumont \& Kies 2017). This law is a continuation of several reforms on the relations between state and Church which had been implemented throughout the incumbent government's term.

\section{Issues in national politics}

Some important laws were voted on in 2018. In February, the majority MPs voted a law on prostitution, introducing a form of 'Luxembourgish model' aiming to combat more effectively pimping and to provide support to prostitutes wishing to change their lives. Still in February, the new hospital law was adopted. It makes important adaptations to the hospital sector, which take into account the demographic evolution of society, the state of health of citizens, and medical and scientific progress. In March, Parliament voted on a law introducing a new tax regime for intellectual property. This law aims to create a favourable tax environment for companies that invest in innovation and research with a view to consolidating and diversifying the Luxembourg economy. In April, the deputies ratified by a majority vote against opposition the law allowing one to sanction the offense of concealment of the face. This text concerns the wearing of the full veil (burqa, niqab). It should be noted that the ban does not concern all public spaces as requested by the main parties of the opposition, the CSV and ADR. In June, the Animal Protection Act was voted. Although it does not prohibit industries based on animals (e.g., for food, clothing, experimentation or entertainment), it aims to further ensure the dignity, life, safety and welfare of animals.

The 2018 Parliament life was also marked by the 'Chamber leaks scandal'. In March, the local public radio station 100,7 uncovered a security flaw on the Parliament's website that allowed people to access non-public information, including details about the results of state examinations, provisional reports from the Intelligence Control Commission, permits for additional funds for the secret services, and internal documents to prepare foreign guests' visits. The Chamber of Deputies has asked the public prosecutor to investigate into 100.7's editor-in-chief, a journalist who worked on the story, and an unknown person who reportedly accessed the leaked data. The journalists' union (ALPJ), the Press Council and political parties such as déi Lénk and Piratepartei have made it known that they condemn this investigation in the name of freedom of the press.

1. The new articles require that electoral lists contain at least 40 per cent of candidates of each gender for the national election and a 50:50 per cent balance for the European 
election for the party to receive the full funding it is entitled to for each percentage point of vote received on top of the basic requirements (presenting full lists and reaching at least 2 per cent of the vote) (Journal officiel du Grand-Duché de Luxembourg 2016).

2. This slogan was mocked by its opponents, the latter considering that the CSV did not take clear positions on several central campaign topics.

3. There were thus 19 female MPs in Parliament at the time of the election.

\section{Sources and further information}

De Jonge, L., \& Biwer, C. (2018). Kampf um Aufmerksamkeit: 'übermannt' in den Medien. Forum 388: 8-9.

Dumont, P., \& Kies, R. (2014). Luxembourg. European Journal of Political Research 53(1): 211-221.

Dumont, P., \& Kies, R. (2016). Luxembourg. European Journal of Political Research 54(1): 175-182.

Dumont, P., \& Kies, R. (2017). Luxembourg. European Journal of Political Research 56(1): 185-191.

Dumont, P., \& Kies, R. (2018). Luxembourg. European Journal of Political Research Political Data Yearbook 57(1): 188-194.

Dumont, P., \& Poirier, P. (2006). Luxembourg. European Journal of Political Research 45(7-8): 1030-1045.

Hennebert, J.-M. (2018). Ce que révèlent les listes des législatives 2018. Paperjam. Available online at: https://paperjam.lu/article/news-ce-que-revelent-les-listes-des-legislatives-2018, last accessed 18 April 2019.

Journal officiel du Grand-Duché de Luxembourg (2016). Mémorial A, 264. Available online at: http://legilux.public.lu/eli/etat/leg/loi/2016/12/15/n2/jo

Kies, R., Poirier, P., \& Schmit, D. (2019). Preliminary results of post-electoral survey ELECT. Unpublished presentation for the Chamber of Deputies.

Service information et presse. (2018). Elections législatives 2018: Résultats officieux. Available online at: https://elections.public.lu/fr/elections-legislatives/2018/resultats.html 